\title{
Evaluation of maize inbred lines for resistance to sugarcane mosaic virus (SCMV) and maize dwarf mosaic virus (MDMV)
}

\author{
L Kuntze ${ }^{1 *, 2}$, E Fuchs ${ }^{1}$, M Grüntzig ${ }^{1}$, B Schulz ${ }^{2}$, \\ U Henning 1, F Hohmann ${ }^{1}$, AE Melchinger 2 \\ 1 Institut für Pflanzenzüchtung und Pflanzenschutz, Martin-Luther-Universität, Postfach 06, D-06099 Halle; \\ 2 Institut für Pflanzenzüchtung, Saatgutforschung und Populationsgenetik (350), Universität Hohenheim, Postfach 700562, \\ D-70599 Stuttgart, Germany
}

(Received 20 May 1995; accepted 4 July 1995)

\begin{abstract}
Summary - Field and greenhouse experiments were performed to evaluate 124 maize inbreds for their reaction to inoculation with sugarcane mosaic virus (SCMV) and maize dwarf mosaic virus (MDMV). Plants were mechanically inoculated twice with SCMV or MDMV and symptoms were evaluated at weekly intervals. The progress of symptom development showed good agreement between inbreds inoculated with SCMV and with MDMV under field and greenhouse conditions. Three inbreds showed complete resistance to SCMV and MDMV across all experiments, 19 inbreds expressed partial resistance, and the remaining inbreds were highly susceptible. In a greenhouse experiment conducted to evaluate 15 inbreds for their reaction to SCMV, MDMV, Johnson grass mosaic virus (JGMV), and sorghum mosaic virus (SrMV), 5 lines were completely resistant to all 4 viruses. Correlations between percentage of infected plants per inbred were high among SCMV, MDMV, SrMV and JGMV.
\end{abstract}

Zea mays $\mathrm{L}=$ maize / resistance / potyvirus

Résumé - Évaluation des lignées de maïs pour leur résistance au virus de la mosaïque de la canne à sucre (SCMV) et au virus de la mosaïque nanisante du maïs (MDMV). Nous avons réalisé des essais en serre et au champ pour évaluer 124 lignées de maïs pour leur réaction à l'inoculation par le virus de la mosaïque de la canne à sucre (SCMV) et par le virus de la mosaïque nanisante du maïs. Les plantes ont été inoculées mécaniquement 2 fois avec le SCMV et le MDMV, et les symptômes ont été évalués chaque semaine. On a constaté un bon accord entre les lignées inoculées avec SCMV et MDMV au champ et en serre sur la progression des symptômes. Trois lignées ont manifesté une résistance complète au SCMV et au MDMV sur l'ensemble des essais. Dix-neuf lignées ont exprimé une résistance partielle, et les lignées restantes se sont avérées très sensibles. Dans un essai en serre pour évaluer 15 lignées pour leur réaction au SCMV, au MDMV, au virus de la mosaïque du sorgho d'Alep (JGMV), et au virus de la mosaïque du sorgho (SrMV), 5 lignées se sont avérées complètement résistantes aux 4 virus. La corrélation entre les pourcentages de plantes infectées par lignées était élevée pour le SCMV, le MDMV, le SrMV, et le JGMV.

Zea mays $L=$ maïs / résistance / potyvirus

* Correspondence and reprints 


\section{INTRODUCTION}

Sugarcane mosaic and maize dwarf mosaic are the most important virus diseases of maize in Europe. Maize dwarf mosaic has been epidemic in several regions of Germany since 1982 (Fuchs and Kozelska, 1984; Huth, 1987). In subsequent years, 2 potyviruses were isolated from maize plants showing mosaic symptoms (Fuchs and Grüntzig, 1990). According to the taxonomy of Shukla et al (1989), these 2 viruses were identified as sugarcane mosaic virus (SCMV) and maize dwarf mosaic virus (MDMV). Both viruses have caused major virus diseases and yield losses in the United States since the mid-1960s (Lansing et al, 1965; Lei and Agrios, 1986). In relation to the total number of plants diseased, further studies in Germany showed a variable percentage of SCMV and MDMV from year to year, SCMV being prevalent in recent years. According to Rosenkranz and Scott (1984), MDMV has a predominately southern distribution, whereas SCMV is mainly found in the northern parts of the USA.

Fuchs and Grüntzig (1994) found a considerable reduction in plant height, total plant weight, and ear weight, when infecting young plants at the end of May. If the increasing trend in SCMVdiseased fields continues, control measures will be necessary. Both SCMV and MDMV are transmitted in a nonpersistent manner by aphids. Therefore, a control of the vectors is not efficient. Chemical control of the viruses is not possible because of the high toxicity of antiviral chemicals. The most efficient control of SCMV and MDMV, from both ecological and economical aspects, is the use of resistant genotypes. Hitherto, resistance to SCMV and MDMV has only been evaluated in US inbred lines and hybrids (Louie et al, 1990; Pataky et al, 1990). We have found no published reports in which resistance has been investigated in European breeding material.

Host response to virus infection is influenced by several factors, including the inoculation protocol (Louie, 1986), physiological stage of the plants at the time of inoculation (Rosenkranz and Scott, 1984; Louie, 1986), and environmental conditions (Louie et al, 1990; Kovacs et al, 1994).

The main objectives of this research were (1) to evaluate a large number of inbreds from the European maize germplasm for resistance to SCMV and MDMV under field and greenhouse conditions; (2) to compare the effect of greenhouse and field conditions on the host reaction; and (3) to screen inbreds for their resistance to
SCMV, MDMV, Johnson grass mosaic virus (JGMV), and sorghum mosaic virus (SrMV) under greenhouse conditions.

\section{MATERIALS AND METHODS}

A total number of 124 European flint and dent inbreds representative of the current European maize breeding material were evaluated for resistance to MDMV and SCMV under field and greenhouse conditions. Field tests were performed at the Experimental Station of the Universität Hohenheim in Eckartsweier near Strasbourg and Stuttgart-Hohenheim, Germany. Inbreds were tested as single-row plots in a randomized block design. Greenhouse experiments were conducted at the Universität Halle, Germany, using 5 seeds per pot.

Virus inocula were prepared from infected young plants. Leaves with mosaic symptoms were homogenated in $0.01 \mathrm{M}$ phosphate buffer $(\mathrm{pH} 7.0)$ in 1:10 dilution. Carborund was added to the inoculum. Plants at the 3to 4-leaf stage were mechanically inoculated twice within a 1-week interval. Inoculation protocols included either rub inoculation of the 2 youngest leaves or an air brush technique (Louie, 1986). Plants were evaluated for virus symptoms at weekly intervals, beginning 7-10 $d$ after the initial inoculation. The number of plants with symptoms was recorded for each scoring date.

\section{Experiment I}

In Hohenheim, for each inbred, 30 plants per row were tested under field conditions with 2 replications in 1993. Half the plants of each row were rub-inoculated with SCMV and MDMV, respectively. Final rating was performed 4 weeks after the initial inoculation.

\section{Experiment II}

Ten to 15 plants per inbred were rub-inoculated with SCMV and MDMV in a greenhouse test in 1993. Virus symptoms were evaluated 4 times.

\section{Experiment III}

Resistance of the inbreds to SCMV was tested in the field with 20 plants per row and 3 replications at Eckartsweier and Hohenheim in 1994. Inoculation was carried out by the air-brush technique. Rating for symptoms was extended to 7 weeks after the initial inoculation.

Based on data analysis, symptomatic reactions of the inbreds were divided into 3 groups: A) plants with a distinct mosaic and a short incubation period (1-4 weeks); B) plants with a longer incubation period (4-7 weeks) with symptoms affecting a limited leaf area; and C) symptomless plants. 


\section{Experiment IV}

Symptomatic reactions of 15 inbreds representing groups A, B and C to inoculation with SCMV, MDMV, JGMV and SrMV were compared under greenhouse conditions in 1995. Twenty-five plants were tested per inbred and virus. Resistant (Pa405) and susceptible inbreds were included as controls. The air-brush technique was applied for inoculation and its success was evaluated by testing the inoculated leaves of each plant with an ELISA after the first inoculation. Four weeks after inoculation, the youngest leaves were tested by an ELISA for presence of SCMV, MDMV, JGMV and SrMV. A final rating was done 7 weeks after the initial inoculation.

\section{RESULTS}

\section{Experiment I}

After field inoculation with SCMV, 27 out of 124 inbreds tested showed no mosaic symptoms (table I). Inoculation with MDMV resulted in 37 inbreds free of symptoms, of which 26 were also symptomless with SCMV. All plants of the remaining inbreds showed distinct mosaic $10 \mathrm{~d}$ after inoculation.

\section{Experiment II}

No symptoms were found on 34 inbreds after inoculation with SCMV and on 31 inbreds after inoculation with MDMV in the greenhouse (table I). A total number of 28 inbreds were completely free of symptoms for both viruses. Distinct virus symptoms were observed in the remaining inbreds.

Most inbreds rated as symptomless in field trials were also symptomless in greenhouse

Table I. Number of 124 maize inbreds showing resistance to SCMV and MDMV under field conditions (Experiment I) and greenhouse conditions (Experiment II) in 1993.

\begin{tabular}{lccc} 
Virus & Field & Greenhouse & Common \\
\hline SCMV & 27 & 34 & 24 \\
MDMV & 37 & 31 & 27 \\
Common & 26 & 28 & 21
\end{tabular}

experiments and vice versa; this applied to both SCMV and MDMV. A common set of 21 inbreds showed no symptoms after inoculation with SCMV and MDMV under field and greenhouse conditions.

\section{Experiment III}

Out of the 124 inbreds examined, 102 lines were highly susceptible with symptoms soon after inoculation (group A) and 19 inbreds showed delayed symptom expression (group B). Three inbreds were completely free of symptoms (group C). Perfect agreement was found between the results at the 2 locations.

\section{Experiment IV}

ELISA confirmed that all plants were positive for virus in the inoculated leaves including the resistant control Pa405. The results of the second ELISA, performed 4 weeks later, agreed with the visual ratings with a single exception.

Of the 15 tested inbreds, 7 expressed distinct symptoms within 4 weeks of the initial inoculation (group A). However, symptom development measured as a percentage of diseased plants 1 week after inoculation was higher with SCMV and JGMV than with MDMV and SrMV. Three inbreds showed symptoms caused by SCMV, MDMV, JGMV, and SrMV after a longer incubation period (group B). Five out of 15 inbreds, including the resistant inbreds identified in Experiment III, exhibited complete resistance to all 4 viruses. Rank correlation among percentages of plants per inbred infected with SCMV, MDMV, JGMV and SrMV were consistently very high among the 15 inbreds tested (table II).

Table II. Correlation between percentage of infected plants for SCMV, MDMV, JGMV and SMV measured on 15 inbreds in Experiment $I V$.

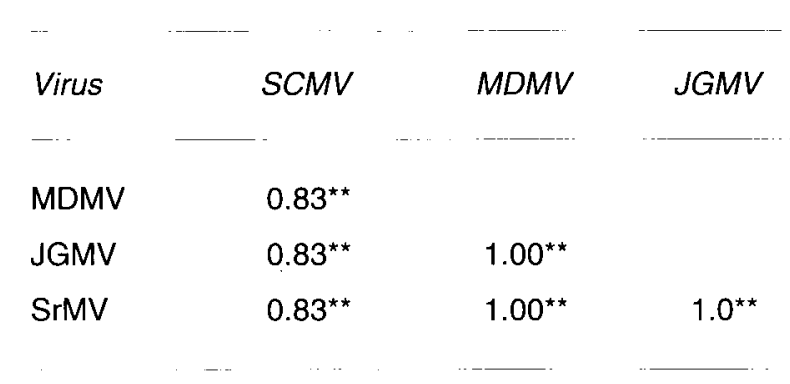

** Significant at the 0.01 probability level. 


\section{DISCUSSION AND CONCLUSIONS}

Under field conditions (Experiment l), we found a greater number of inbreds susceptible to SCMV than to MDMV. A similar observation was made by Louie et al (1990), when testing US public inbreds. They found most inbreds to be more susceptible to SCMV than to MDMV in the field, but the genotypes averaged 59 and $35 \%$ infected plants per inbred, respectively. By contrast under greenhouse conditions (Experiment II) more inbreds were susceptible to MDMV than to SCMV. Louie et al (1990) also found higher rates of MDMV than of SCMV infected plants for some inbreds in the greenhouse. However, these findings were not consistent for all of their inbreds. Differences from the results presented here are very likely due to an entirely different set of European inbreds having been used in our study.

Comparison of field and greenhouse data from Experiments I and // showed that the number of inbreds resistant to SCMV increased under greenhouse conditions, whereas more inbreds were resistant to MDMV in the field. It is known that the virulence of SCMV and MDMV as well as the host plant response can vary over a wide range depending on the environmental conditions. Louie et al (1990) attributed the different reactions of inbreds under greenhouse and field conditions mainly to differences in plant development and physiology of greenhouse plants. Tu and Ford (1968) reported that plants pretreated at higher temperatures were more susceptible to MDMV than those pretreated at lower temperatures. They also found increased susceptibility under nutrient stress. According to Scott et al (1969), variability in reaction to MDMV can be due to the microenvironment of individual plants. Therefore, the varying results in Experiments I and // regarding the share of symptomless plants after inoculation with MDMV and SCMV under field and greenhouse conditions can be largely explained by complex interactions among virus strains, plant genotype and influences of the environment.

Three inbreds proved to be completely resistant for SCMV under field conditions after inoculation with an air-brush technique (Experiment III) and 19 inbreds showed delayed symptom expression. These findings were in contrast with the results of Experiments $I$ and $/ /$ with 27 lines exhibiting resistance to SCMV. The striking difference in number of resistant inbreds can be explained mostly by the extended rating period of 7 weeks after inoculation in Experiment III, although variability in the test conditions cannot be ruled out as another cause. A longer incubation time of some inbreds and hybrids was also reported by Kovacs et al (1994). They suggested that an extended incubation period under the same conditions provides a certain degree of virus resistance to these genotypes. In a genetic study of resistance to MDMV, McMullen and Louie (1989) observed a delayed symptom appearance and reduced symptom severity of host plants. They concluded that the progress of symptom expression depends on the number of resistance genes involved and identified a major gene for MDMV resistance on chromosome 6 . A change of the inoculation protocol from rub inoculation to the air-brush technique should hardly have contributed to the differences between experiments, because both methods are known to result reliably in high levels of infection.

In experiments for evaluation of resistance, disease ratings should be taken for at least 7 weeks after inoculation in order to obtain complete information about the materials tested. Whether delayed symptom development as expressed by the inbreds of group B will suffice to reduce yield losses will be investigated in future experiments.

When comparing the host reaction of 15 inbreds to inoculation with 4 related potyviruses under greenhouse conditions (Experiment IV), progress of symptom development indicated a higher virulence of SCMV and JGMV compared to MDMV and SrMV. However, correlation for the reaction to all viruses was high (table II) suggesting a similar resistance mechanism to the 4 potyviruses. Louie et al (1990) determined the genetic basis of resistance in inbred Pa405 to 3 strains of SCMV and 2 strains of MDMV using translocation markers, morphological and molecular markers. They postulated 1 gene or linked genes on either the short arm or the proximal region of the long arm of chromosome 6 in inbred Pa405 controlling resistance to the virus strains.

Two inbreds with delayed symptom expression in Experiment III showed a complete resistance to all 4 potyviruses under greenhouse conditions (Experiment IV). This might be due to the influence of different environments as was stated before with regard to Experiments / and II.

Experiments focussing on the evaluation of host-pathogen interactions or concentrating on resistance mechanisms should be done under both field and greenhouse conditions in order to estimate interactions with a variety of factors influencing plant and virus. In this case, an 
ELISA should be performed after the final rating to exclude possible escapes.

For breeding purposes field experiments will be the method of choice. When testing for SCMV resistance in the field, we found good agreement between locations (Experiment III), indicating that screening for resistance in one environment may suffice. Further research is needed to confirm these findings. The results of visual rating and ELISA test corresponded well (Experiment IV). Therefore, for practical purposes an ELISA test may not be necessary. However, rating of symptoms should be extended to at least 7 weeks after the final inoculation in order not to miss plants with delayed symptom development.

\section{ACKNOWLEDGMENTS}

We acknowledge B Devezi and F Mauch for excellent technical assistance and I Einecke for serological examinations. We thank $D$ Klein for providing seeds and conducting the field experiments at Eckartsweier and $M$ Messmer for scoring the virus symptoms in 1993.

\section{REFERENCES}

Fuchs E, Kozelska S (1984) Zum Auftreten und zur Schadwirkung des Europäïschen Maismosaik Virus (EMMV) in der DDR sowie Ergebnisse der Prüfung der Anfälligkeit von Inzuchtlinien und Hybriden. Nachrichtenblatt Pflanzenschutz DDR $38,162-164$

Fuchs $E$, Grüntzig $M$, Kozelska $S$ (1987) Untersuchungen zum Vorkommen von Serogruppen des Maisverzwergungsmosaikvirus (maize dwarf mosaic virus, MDMV) in der DDR. Zentralb/ Mikrobiol 142, 41-47

Fuchs E, Grüntzig M (1990) Zur Ökologie der Potyviren an Mais in der DDR. Arch Phytopathol Pflanzenschutz 26, 329-339

Fuchs E, Grüntzig M (1994) Influence of sugarcane mosaic virus (SCMV) and maize dwarf mosaic virus
(MDMV) on the growth and yield of 2 maize varieties. J Plant Dis Protec 102, 44-50

Huth W (1987) Maisvirosen in der Bundesrepublik Deutschland. Mais 3, 18-20

Kovacs G, Gaborjanyi R, Duong HN, Vasdinyei R (1994) Susceptibility of maize inbred lines and hybrids to potyviruses under greenhouse and field conditions. Cereal Res Commun 4, 347-351

Lansing EW, Alexander LJ (1965) Maize dwarf mosaic virus, a new corn disease. Phytopathology 55, 802804

Lei JD, Agrios GN (1986) Mechanisms of resistance in corn to maize dwarf mosaic virus. Phytopathology $76,1034-1040$

Louie R (1986) Effects of genotype and inoculation protocols on resistance evaluation of maize to maize dwarf mosaic virus strains. Phytopathology 76, 769-773

Louie R, Knoke JK, Findley WR (1990) Elite maize germplasm: reactions to maize dwarf mosaic and maize chlorotic dwarf viruses. Crop Sci 30, 12101215

McMullen MD, Louie R (1989) The linkage of molecular markers to a gene controlling the symptom response in maize to maize dwarf mosaic virus. $\mathrm{Mol}$ Plant Microb Interact 2, 309-314

Pataky JK, Murphy JF, D'Arcy CJ (1990) Resistance to maize dwarf mosaic virus, severity of symptoms, titer of virus, and yield of sweet corn. Plant Dis 74, 359-364

Rosenkranz E, Scott GE (1984) Determination of the number of genes for resistance to maize dwarf mosaic virus strain $A$ in 5 corn inbred lines. Phytopathology 74, 71-76

Scott GE, Rosenkranz EE, Nelson IR (1969) Host reaction to maize dwarf mosaic virus from Mississippi and Ohio. Plant Dis Rep 53, 933-935

Shukla DD, Tosic M, Jilka J, Ford RE, Toler RW, Langham MAC (1989) Taxonomy of potyviruses infecting maize, sorghum, and sugarcane in Australia and the United States as determined by reactivities of polyclonal antibodies directed towards virus-specific $\mathrm{N}$-termini of coat proteins. Phytopathology 79, 223-229

Tu JC, Ford RE (1968) Effect of temperature on maize dwarf mosaic virus infection, incubation, and multiplication in corn. Phytopathology 59, 699-702 